In the 1970s a grammar-based psycho-pragmatics emerged, looking for outer frames of a grammar (and mainly syntax) centred vision of language. It was analytic and its main purpose was to relate language processing to the representation of the physical world. Its typical paradigms were sentence/picture verification (Clark and Chase), and testing stored knowledge (three is an even number). These experiments showed a preference for affirmative and tie propositions. Another favourite topic of the time was separating lexical and encyclopaedic knowledge, for example, in anaphora interpretation (The girl met the policeman and the architect. He asked for her ID card, Pléh) and in treating inferences in cases like The girl took out the basket from the trunk. The beer was warm (Kintsch).

The second wave started around 2000 with the program of Ira Noveck and Dan Sperber as experimental pragmatics based on the philosophy of Paul Grice. It is part of the general move of cognitive science towards social models, with a commitment of language processing to Theory of Mind (ToM). Regarding language processes, this is a more holistic approach, assuming a few rules, or as Sperber does, a single principle, the principle of relevance. In the experiments, the most important issue is not the representation of the world, but the representation of mental states of the partners. At the same time, in its studies of quantification (some vs. all), metaphors and irony processing, it has philosophical commitments and inspirations.

Keywords: pragmatics, knowledge-based processing, ambiguity, Theory of Mind (ToM), relevance.

\title{
A vérszerződéstől a vércikiig: A vÉR kulturális konceptualizációja a magyar nyelvben*
}

\section{Bevezetés}

A test és az elme közötti kapcsolat kérdésköre számos tudományt érint, az orvostudománytól kezdve a pszichológián át a filozófia, a nyelvtudomány, a szociológia vagy a teológia területéig. A nyelvtudományon belül az embodiment kifejezés (többféle fordítása létezik: testesültség, testbeágyazottság, megtestesültség) átfogóan arra a jelenségre utal, ahogyan az emberi test a nyelvhasználatban a gondolkodásunkat meghatározza, formálja. A testbeágyazottság Gibbs szerint nem más, mint „megérteni egy egyén testének a szerepét az ő mindennapos, szituációkban megvalósuló megismerő tevékenységében" (situated cognition) (Gibbs 2006: 1, saját forditás). A testbeágyazottság hipotéziseként (embodiment hypothesis) elterjedt elmélet Lakoff és Johnson (1980) azon megfigyelésére vezethető vissza, amely szerint a fogalmi rendszer és a nyelvi szerkezetek nagymértékben metaforikusak, ezek pedig jórészt a fizikai testi tapasztalatokon alapulnak (vö. Johnson 1987). A testmetaforákban egyirányú metonimikus és metaforikus folyamatokról beszélhetünk, ahol a test forrástartományként funkcionál, amelyet különböző absztrakt céltartományokra képezünk le. A tendencia érvényesnek tünik annak ellenére, hogy ellenpéldákat is találunk: térdkalács, körömágy, szájpadlás, fülkagyló, hajtö, sípcsont stb.

\footnotetext{
* A tanulmány az EFOP-3.6.1-16-2016-00017 számú Nemzetköziesítés, oktatói, kutatói és hallgatói utánpótlás megteremtése, a tudás és technológiai transzfer fejlesztése mint az intelligens szakosodás eszközei a Széchenyi István Egyetemen című pályázat támogatásával készült.
} 
A nyelv testbeágyazottsága kapcsán Gibbs hangsúlyozza, hogy „a test nem kultúrafüggetlen objektum, mivel a testbeágyazott tapasztalat minden vonatkozását kulturális folyamatok határozzák meg" (Gibbs 2006: 13, saját forditás). CharterisBlack (2001: 273-4) pedig a testbeágyazott kifejezések konnotációját és értékelését említi kultúraspecifikus tényezőként. Az elmúlt években számos tanulmány és tanulmánykötet jelzi azt az érdeklődést, amely a nyelv és a test kapcsolatának kulturálisan eltérő felfogását vizsgálja. Fontos irányt képez a „testbeágyazottság a testrészekben" (embodiment via body-parts) témakör, amely a testrészek és az egyéb tartományok, azaz az érzelmek, a kogníció, a személyiségvonások, a társadalmi értékek stb. közötti kapcsolatot elemzi a különböző nyelvekben (Sharifian et al. 2008; Maalej-Yu 2011; Brenzinger-Kraska-Szlenk 2014; Kraska-Szlenk 2020). Maalej és Yu azt hangsúlyozza, hogy a testbeágyazottság fiziológiai és kulturális folyamat egyaránt, amely kontinuumot alkot (Maalej-Yu 2011: 9; vö. még Maalej 2004), és a minél több nyelvre kiterjedő vizsgálatok fő kutatási kérdései a következők (Maalej-Yu 2011: 2):

a) A test mely részét alkalmazzuk egyes érzelem, személyiségjellemző, mentális állapot vagy kulturális érték kifejezésére?

b) Milyen szerkezet(ek) (pl. metafora, metonímia, képi séma) jelenik/jelennek meg a konceptualizációban?

c) Vajon a különbözö kultúrákban azonos testrésszel fejezik ki ugyanazt az érzelmet, személyiségjellemzőt, mentális állapotot vagy kulturális értéket?

d) Milyen következtetések vonhatók le a testbeágyazottság hipotézisére vonatkozólag?

Mivel a testrészek fogalmi hálózatában az egyes konceptualizációk a testrészek csupán egy vagy néhány jellemzőjéhez kapcsolódnak, nemcsak a testrész és a konceptuzalizáció között fejthető fel a kapcsolat, hanem komplexebb összefüggésrendszerröl is beszélünk. Ezért a fenti négy kérdést érdemes kiegészíteni még a következővel:

e) Egy adott testrész mely jellemzője, funkciója profilálódik egy-egy konceptualizációban?

A kulturális testbeágyazottság a kulturális konceptualizáció fogalmán belül értelmezhetö, amely a nyelv, a kultúra és a kogníció összefüggésére utaló fogalom (Sharifian 2003, 2011, 2017). A kulturális konceptualizációk ,a kulturális csoportok tagjai között megosztott reprezentációs hálózatok", vagyis az adott közösség világszemléletének (kulturális kogníciójának) kifejeződései metaforák, sémák és kategóriák formájában (Sharifian 2011: 5). A kulturális metaforák alapvetően fogalmi metaforák (Lakoff-Johnson 1980), definitív tulajdonságuk azonban az is, hogy egy közösség kulturális tapasztalatát, hiedelmeit, vallási-világnézeti szemléletét reprezentálják (Baranyiné Kóczy 2017). A metaforák kultúraközi különbségei a forrásés céltartományok közötti megfeleltetések eltérésében vagy például egy generikus 
séma specifikálásában is megfigyelhetők (Kövecses 2002). Ezek különböző fizikai, társadalmi, kommunikatív szituációs stb. tapasztalatból és más kognitív preferenciákból erednek, ahol minden esetben kulturális hatással kell számolni (Kövecses 2005: 232, 246). A metafora szemantikai szerkezetét, használatát, konnotációit univerzális és kultúraspecifikus jegyek egyaránt alkotják; kulturális metaforáról az utóbbi jegyek azonosíthatóságának és a kulturális kognícióban való beágyazottság mértékének a függvényében beszélhetünk (Baranyiné Kóczy 2017). A testrészek figuratív kifejezéseit akkor nevezhetjük elsősorban kulturális metaforáknak, ha a testrészeket egy kulturális közösség saját világnézete, értékrendje szerint alkalmazza absztrakt fogalmakra - a test részeinek metaforikus szerepe költői müvekben más jellegü vizsgálatot jelent (pl. Büky 2012).

Az itt körvonalazott kulturális testbeágyazottság jelenségének vizsgálatához kapcsolódva a tanulmány célja rekonstruálni a magyar vér fogalom kulturális konceptualizációit, feltárni a kulturális kognícióban fellelhető gyökereit és azonosítani a tartományokban a vér jellemző profiljait. A nyelvi adatokat a kézikönyvekben, szótárakban fellelhető vért tartalmazó kifejezések alkotják, amelyeket a Magyar nemzeti szövegtár korpuszvizsgálata egészít ki (MNSz., vö. Oravecz-Váradi-Sass 2014). A vizsgálat nehézsége, hogy egy kifejezés pontos jelentése az adott kontextusban határozható meg, így a kvalitatív jellegü vizsgálathoz is elengedhetetlen a korpuszadatok elemzése; emellett szükségszerüen nem tud kizárni bizonyos mértékü szubjektív értelmezést, amelyet a korpuszadatok pontosítanak; végül a kategóriák definiálása sokszor nem egyértelmü a határok elmosottsága miatt. A dolgozat felépítése a következő: a Bevezetést követően a 2. fejezet áttekinti a vérrel kapcsolatos korábbi nyelvészeti vizsgálatokat, majd a 3. fejezet a magyar vÉR fogalom konceptualizációit elemzi különös hangsúlyt fektetve a kulturális tényezőkre. A 4. fejezet azt vizsgálja, hogy az egyes konceptualizációkban a vÉR melyik profilja kerül elötérbe. A tanulmányt a főbb eredmények összegzése zárja.

\section{A vÉR vizsgálata a nyelvészeti kutatásokban}

A vérhez mind a nyugati, mind az egyéb kultúrákban kiterjedt szimbolika füződik: vitalitással, szenvedéllyel, élettel, családi kötelékkel, de egyúttal halállal és agresszióval is asszociálják. Victor Turner antropológus szerint a vér domináns rituális szimbólum (Turner 1977), amelynek figuratív használatával kapcsolatban elsősorban a 'faj, eredet' jelentés vált elterjedté (Mulsoff 2007), valamint az érzelmekkel való kapcsolat: a vér lehülése, például a megfagyott a vér az ereiben kifejezés (angolban: blood running cold) a félelmet jelenti (Kövecses 1990), míg a vér megemelkedett hőmérséklete, például a felforr a vére kifejezés (angolban: boiling blood) dühöt (is) jelez a két nyelvben (Kövecses 1990, 2002; Lakoff-Kövecses 1987).

A vér metaforikus jelentéseinek feltárását célozza Charteris-Black (2001) a Bank of English korpuszon végzett vizsgálata, amelyben három fö, univerzálisnak tünő „,fogalmi kulcsot" (conceptual key) azonosít, ezek A VÉR A ROKONSÁG HELYETT, A VÉR AZ ÉLET HELYETT és A VÉR VÉRMÉRSÉKLET. A szerző a fogalmi kulcs terminust úgy értel- 
mezi, mint olyan ,alapvető állítás[t], amely a nyelv és a gondolkodás között hidat képez. Tartalmazhat fogalmi metaforát, fogalmi metonímiát, konvencionális forgatókönyveket vagy a hétköznapi tapasztalatból levont más típusú tudást" (CharterisBlack 2000: 282, saját fordítás). Charteris-Black a vér és az érzelmek kapcsán megállapítja, hogy ezek a metaforák az ÉRZELEM TARTÁLYBAN LEVŐ FOLYADÉK fogalmi metaforára mint alapvető képi sémára vezethetők vissza, amely egyébként számos érzelem konceptualizációjában is felfedezhető (Kövecses 1990). A vér tehát az a folyadék, amellyel a test mint tartály megtelik vagy amelyböl kiürül (CharterisBlack 2001: 273).

A vér figuratív értelmü ROKONSÁG, SZÁRMAZÁs konceptualizációja számos nyelvben megtalálható, így a német Blut, az amhara (amely egy afroázsiai sémi nyelv) däm, a hausza jini vagy a török kan szóban (Kraska-Szlenk 2014: 56). További példák a VÉR A ROKONSÁG HELYETT konceptualizációra:

(1) angol: in your blood (véredben [van]), blue blood (kék vér), own flesh and blood (saját húsa-vére, azaz tulajdon vére, leszármazottja), blood is thicker than water (szólás: a vér nem válik vízzé, olyan értelemben, hogy a rokoni kötelék mindennél fontosabb) (Charteris-Black 2001);

(2) maláj: darah putih (fehér vér), darah jernih (tiszta vér, mindkét kifejezés a jólneveltségre utal) (Charteris-Black 2001: 278);

(3) szuahéli: uhusiano wa kidamu (vérkapcsolat, rokoni kapcsolat), huyu ni damu yangu (ő az én vérem, azaz gyermekem vagy közeli rokonom), Damu nzito kuliko maji (szólás: a vér nem válik vízzé) (Kraska-Szlenk 2014: 56);

(4) lengyel: krewny (rokon), pokrewieństwo (rokonság), ahol mindkét kifejezés a krew (vér) tőböl ered; więzy krwi (vérkötelékek, azaz rokonság), w ich żłach plynie ta sama krew (ugyanaz a vér folyik az ereinkben, azaz rokonok), moja krew (az én vérem, azaz gyermekem) (Kraska-Szlenk 2014: 56).

Egy másik fontos konceptualizáció a VÉR AZ ÉLET HELYETT, amelyet olyan angol kifejezések példáznak, mint getting blood out of a stone (szólás: vért csiholni egy kőből, amely körülbelül azt jelenti, hogy egy személyt olyan tettre próbáljuk rávenni [sikertelenül], amelyre ö a személyisége vagy hangulata miatt nem alkalmas), fresh blood (friss vér), a flesh and blood (hús és vér), to have blood on your hands (vér tapad a kezedhez), to scent blood (vért szimatol) (Charteris-Black 2001: 279).

A Charteris-Black által említett harmadik fogalmi kulcs a VÉR VÉRMÉRSÉKLET, amely az érzelmek fiziológiai tapasztalataival függ össze, és gyakran metonimikus forrásként funkcionál a test figuratív kiterjesztéseiben. Amikor erős dühöt érzünk, azt tapasztaljuk, hogy a vér a fejünkbe tódul: a rush of blood to the head (fejbe szökik a vér). Más kifejezések viszont egyértelmüen metaforikusak, mint sweat blood (vért izzad). A vér figuratív használata az érzelmek kifejezésében megtalálható az angolban: in cold blood (hidegvérrel), blood, sweat and tears (vér, verejték és könnyek, azaz nagy nehézségek árán sikerül valami), make your blood boil (felforr a véred), make your blood run cold/freeze (megfagy az ereidben a vér) (CharterisBlack 2001: 283). Számos példa található a malájban is: darah manis (édes vér, 
azaz könnyen megbirkózik a veszéllyel), darah merah (vörös vér, azaz bátor), darah perwira (hősies vér, azaz bátor), darah hati (vérmáj, azaz bosszús), darah panas (forró vér, azaz hirtelen haragú), darah kering (száraz vér, azaz kegyetlen), darah tersembur (a vér kiserken a szájból, azaz ijedt) vagy darah muda (fiatal vér, azaz meggondolatlan) (Charteris-Black 2001: 284). Számos példa található a vÉR mint VÉRMÉRSÉKLET konceptualizációra a tunéziai arab nyelvben is, például: damm-u sxun (forró a vére / forró vérü, azaz ingerlékeny), damm-u baarid (hideg a vére, azaz nyugodt) (Maalej 2008: 405). Maalej felhívja azonban a figyelmet arra, hogy míg egyes kifejezések látszólag az európai klasszikus-középkori kulturális kontextust meghatározó testnedvelméletre utalnak (Geeraerts-Grondelaers 1995), a megfeleltetések nem egyértelmúek: például a forró vér a tunéziai arabban nem a szangvinikus, hanem a kolerikus vérmérsékletet jellemzi (Maalej 2008).

A magyar nyelvben a test konceptualizációja és a testi metaforák, metonímiák vizsgálata kevéssé kutatott terület. Meg kell említeni Csábi doktori disszertációját, amelyben a magyar és az amerikai angol szólásokban elemezte a testrészek alternatív konceptualizációját (Csábi 2005), valamint Bańczerowski a KÉz, a FEJ és a SzÍv nyelvi képét rekonstruáló tanulmányait (Bańczerowski 2003, 2007; Bańczerowski-Dziewonska-Kiss 2013). Újabban Baranyiné Kóczy kulturális nyelvészeti megközelítésből elemezte a szEM konceptualizációját (Baranyiné Kóczy 2018, 2020), valamint a FEJ konceptualizációit a GONDOLKODÁsT kifejező metaforikus kifejezésekben (Baranyiné Kóczy 2019). Kifejezetten a vér figuratív használatára irányuló nyelvészeti kutatást Simó végzett magyar-amerikai viszonylatban először sakktémájú cikkekben (Simó 2008), majd pedig kiterjedt korpusznyelvészeti elemzést alkalmazva vizsgálta a két nyelvben a fogalom gyakoriságát, használati mintázatait (Simó 2011). Két fő céltartományt különböztet meg, az érzelem és a lényeg (essence) halmazát, amelyből az utóbbi további alterületekre bontható, úgymint eredet, jelentőség, minőség és élet. Az összehasonlító vizsgálatban négy kifejezés amerikai angol és magyar megfelelöjét veti össze: in his/her blood / vérében, sweat blood / vért izzad, in cold blood / hidegvérrel, blood (is/was) boil(ing/ $e d / s)$ / forr $(t)$ a vér(e/m/ed/ünk/ük). Az elemzés eredményeként megállapítja, hogy két párhuzamos kifejezés megközelítően egyforma gyakorisággal fordul elő a két nyelvben, míg egy az amerikai, egy pedig a magyar korpuszban gyakoribb. Másodsorban kiemeli, hogy a kifejezések használata, pozitív és/vagy negatív helyzethez való kötődése jelentős különbségeket mutat a nyelvekben.

\section{A VÉR kulturális konceptualizációi a magyar nyelvben}

\subsection{A VÉR mint SZÍN}

A vér egyik elsődleges asszociációja a piros szín. A vörös színnév mellett több kifejezésben utal egy entitás piros színére, például a vérnarancs húsának színére, a vércse esetében a madár hátán lévő piros tollazatra, a vörheny (skarlát) neve pedig a vöröses bőrkiütésekből ered. Ezekben az esetekben a vér színe profilálódik. 


\subsection{A VÉR mint HALÁL}

A vér látványa elsősorban a veszélybe került, sérült embert, esetleg halottat idézi fel. Az idetartozó kifejezések gyakran eröszakra utalnak, mint vérontás, vérszomjas, vér tapad a kezéhez (olyan személy, aki gyilkosságot követett el), vérengzés, vérfürdö (nagyon véres harc), vérzivataros század (olyan évszázad, amely háborúkkal volt tele) - az utóbbi két kifejezés esetében A vÉR MENNYISÉGE A HALOTTAK SZÁMA metonímia jelenik meg. Az ÉRVELÉS HÁBORÚ metafora alapján a vér gyakran a vita kontextusában reprezentálódik (1-2):

(1) Nem lehet az ellenzéki és kormánypárti politikusokat zárt térben sokáig magukra hagyni, mert ott vér folyhat.

(2) egy ügyet véd az utolsó csepp vérig

Az idetartozó vérdíj szónak kulturális kontextustól és tudományterülettől függően különböző értelmezései léteznek (ÉrtSz.):

a) A büntető hatóságok elől rejtőzködő személy(ek) kézrekerítője vagy nyomravezetője részére kitüzött jutalomdíj.

b) A gyilkos által megölt személy hozzátartozóinak engesztelésül, a vérbosszú megváltására fizetett összeg vagy átengedett vagyontárgy.

c) 〈A rendi és feudális magyar jogban〉 az a bírság, amelyet jogtalan erőszak, hatalmaskodás körébe eső büncselekmény elkövetőjére vetettek ki.

d) (régies, költői használatban) vérbosszú, véres megtorlás.

Figyelemre méltó, hogy a b) jelentésben a vérrel összefüggésben a HALÁL konceptualizációja mellett a ROKONSÁGé is megjelenik.

A VÉR mint HALÁL konceptualizációval kapcsolatban két kulturálisan beágyazott kifejezést érdemes megemlíteni. A vértanú olyan személyt jelent, aki tanúságot tesz egy vallás vagy hit mellett, ezért önként vállalja a halálbüntetést. A másik kifejezés az első vérig, amely az első vérig tartó párbajozási tradícióból ered. Ez a rituálé évszázadokon át volt elterjedt az európai nemesség körében, célja a férfi becsületének és hírnevének megvédése volt, amely egyben a férfiak identitásának meghatározó eleme volt. A párbaj végét az „első vér”, azaz az első sérülés jelentette, ahol a sebeket ejtő fél győztesként került ki a becsületért vívott küzdelemből.

\subsection{A VÉR mint ROKONSÁG}

A magyar nyelvben rengeteg olyan vérrel összefüggő kifejezés található, amely rokonságot jelent: testvér (amely az „egy test, egy vér” összetételéből származik), fivér, növér, vérrokon, vér szerinti szülö, Véreim! (rokonokra és a nemzet tagjaira vonatkoztatva), valamint lovakkal kapcsolatban is találunk példákat, mint telivér (fajtisztán tenyésztett ló), félvér (két különböző fajta keresztezésével létrejött egyed, de emberre is vonatkozhat). Az a hagyományos vélekedés, amely szerint a szárma- 
zás örökítőanyaga a vér, a vérvonal szóban ragadható meg leginkább, amely jelzi, hogy ez a testi folyadék, amely a genetikai állományt örökíti tovább egy családban generációról generációra. A vér minősége tehát mindig is központi téma volt. A több nyelvben is jelenlevő kékvér arisztokrata eredetet jelez. Brewer állítása szerint a szó a spanyol nyelvből ered, a kék erekre utal, amelyek a fehér és áttetsző bőr alatt váltak láthatóvá olyan embereknél, akik nem keveredtek a mór vérrel. Átvitt értelemben a magas társadalmi státuszú családokat jelenti tehát (Kirkpatrick 1992: 118). A vérfertözés közeli rokonok közötti szexuális kapcsolatot jelent.

A VÉR mint GENETIKAI ÁLLOMÁNYT HORDOZÓ ANYAG konceptualizációjának kiterjesztése figyelhető meg a vérbeli szóban, amely valamilyen kiemelkedő emberi tulajdonságot jelent. Míg a vérbeli fónemes olyan személyt jelez, akinek a felmenői szintén arisztokraták voltak, a hasonló vérbeli filozófus/szinész/szakács összetételek olyan egyedekre utalnak, akik kiemelkedő szakértelemmel, tehetséggel bírnak a filozófia, színmüvészet vagy szakácsmüvészet területén.

A vÉR mint ROKONSÁG olyan kulturális konceptualizáció, amely a magyar kulturális kognícióban bizonyos mértékig még ma is él. Erre utalnak azok a korpuszadatok, amelyek szerint az ember identitásának fontos részét képezi a vér minősége és eredete.

(3) Tulajdonképpen nem tudom, hogy a véradás jó dolog vagy sem, ezen sokszor gondolkoztam már. Sokszor úgy érzem, természet ellen való dolog, a vér az nem csak egy folyadék. Ugyanígy vagyok a szervátültetéssel is.

(4) Én azért nem adok vért, mert megőrzöm a tisztaságot! Nem adom senkinek a tisztán öröklött vérem, hogy aztán továbbvigye valami mutáns...!

A fenti vélemények szerint a vér „nem csak egy folyadék”, hanem olyan anyag, amely a fizikai tulajdonságokat és a karakterjegyeket örökíti és biztosítja a hordozója számára. Az öröklött vér „tiszta”, és így is kell megőrizni, míg a véradás jóval túlmutat a biológiai anyag átadásán, nemkívánatos keveredést eredményez, illetve a vér ezáltal olyan személy birtokába jut, aki arra jogosulatlan. Ennek alapján minősíti ,természet ellen való dolognak” az egyik megnyilatkozó, holott biológiai tények nem támasztják alá ezt a kulturális vélekedést.

A vér mint embereket összekapcsoló anyag másik két kulturális kifejezésben is megjelenik: vérszerződés és vértestvérség. Ezek a fogalmak egy olyan kulturálisan beágyazott rítusra utalnak, amelyben két nem rokoni kapcsolatban álló ember (többnyire férfi) között testvérjellegü kapcsolat jött létre. A több kultúrában is jelen lévő szertartás szerint két szövetséges néhány csepp vért ad a másiknak, amelyet elfogyasztanak (Hauser-Schäublin 1993), ezáltal intim, egyenlőségen alapuló kapcsolatot kötve, amelyben hüséget eszküsznek egymásnak (Evans-Pritchard 1933: 400). Ez a tradíció több afrikai kultúrában elterjedt volt, érdekes módon olyanokban is, ahol a VÉR nem kapcsolódott a ROKONSÁG konceptusához, például a (dél-szudáni) zande nyelvben (Evans-Pritchard 1933). A magyar kulturális hagyományban és így a kulturális kognícióban kiemelt vérszerződés eseménye a 9. században történt a hét vezér részvételével, egyben ez volt az első magyar alapszerződés. A vérszerző- 
dés mint rítus a korabeli magyar szokásjog szerint a különlegesen erős fogadalomtételek egyik formai kelléke volt, esküvel megerösítve. A magyar hagyományban a nem rokoni kapcsolatban álló férfiak kisebb vágást ejtettek az ujjukon, kezükön vagy alkarjukon, majd összeérintették, jelezve, hogy a vérük egymás ereiben folyik. A másik verzió szerint úgy fogadták testvérré egymást, hogy egy kehelybe csorgatták a vérüket, és mindannyian ittak belőle (MNL. 5).

Végül a ROKONSÁG konceptualizációjához kötődik a vérbosszú és a véreskü fogalma is. Első látásra ezek a kifejezések inkább a VÉR, mint HALÁL konceptusát idézik fel, mindkét esetben azonban egy családtag (vérbeli kapcsolat) halálának bosszújáról van szó, amely szerint valaki a gyilkos vagy annak egy rokona halálával bosszulja meg a családján esett sérelmet. Gyakran a tett motivációja az ősök szellemétől való félelem volt, így a véreskü apáról fiúra szállt. Ez a hagyomány számos közösségben élt, Korzikától kezdve Szardínián, a Balkánon, a Kaukázuson át a germán, arab közösségekig, Szicíliáig és Albániáig. Magyarországon a cigány és a székely közösségekben az 1930-as évekig gyakorolták a hagyományt.

\subsection{A VÉR mint EMBERI TERMÉSZET}

Vannak olyan kifejezések is, amelyekben a vér az emberi természetet fejezi ki. Már szó volt róla, hogy a ROKONSÁG és az EMBERI TERMÉSZET céltartománya összefügg a VÉR mint GENETIKAI ÁLLOMÁNYT ÉS KARAKTERT HORDOZÓ ANYAG konceptualizációban. Egyes esetekben nehéz szemantikailag szétválasztani a két tartományt (5):

(5) Ez inkább volt a német vér rendszerető tulajdonságának tudható.

A „német vér” a német nemzetet és a nemzeti karaktert is jelenti egyidejűleg.

(6) A vér nem válik vízzé.

A szólás többféle értelmezése létezik, amelyekben a ROKONSÁG és az EMBERI TERMÉSZET keveredése figyelhető meg (Szemerkényi 2009: 1434):

a) Egy jó jellem sosem változik.

b) Mindenki a saját családjához húz.

c) A családi kötelék kölcsönös segítségen alapul.

d) A szülök értékes tulajdonságai a gyermekekben öröklődnek tovább.

e) A nagylelkü, családcentrikus emberek nem változnak.

A rokonság és a (családra jellemzö) emberi tulajdonságok szorosan összekapcsolódnak a magyarban. Az alábbi példákban az EMBERI TERMÉSZET a domináns, de a ROKONSÁG is megfigyelhetö.

(7) A hazudozás a vérévé vált.

(8) Az idegenekkel való bizalmatlanság vérünkbe ivódott. 
Összességében elmondható, hogy a vér származékaként rengeteg olyan kifejezés létezik, amely tulajdonságokat fejez ki; a forrástartományban a vér különböző tulajdonságai jelennek meg, mint a hőmérséklete, sürüsége vagy a mennyisége. Maga a vérmérséklet szó is erre utal, a vér és a mér igetőből származó összetételként.

A vérmes kifejezés szerint egy egészséges emberben nagy mennyiségü és sürü vér van, amely „erős, szenvedélyes, forróvérü” karaktert eredményez (ÉrtSz.). További tulajdonságot jelentő kifejezések:

(9) heves vérmérsékletü

(10) tüzes vérü

(11) forróvérü

(12) hidegvérü

(13) Csigavér!

(14) halvérü

(15) könnyűvérü (nő)

(16) sürü vérü

A sürü vérü jelentése szenvedélyes vagy felelőtlen (16). Érdekes módon a sürü vér és a könnyü vér (egymásnak közel ellentétei) is szenvedélyes, szexuálisan felelötlen személyt jeleznek, a sürü vér azonban elsősorban férfiakra, a könnyü vér pedig nőkre használatos.

(17) A felelősségtudat. Az hiányzott belőle. [...] Nem bírt a sürü vérével.

A vér a szenvedélyes természet „,̈zemanyaga”, amelyet a hajtja a vére kifejezés is jelez.

A (9)-(16)-os példák közül jó néhány a négy testnedv modelljeként ismert középkori (föként a 16-17. században elterjedt) filozófiai elmélethez köthető, amely az emberi személyiségtípusokat az egyes testnedvek arányából fakadó vérmérsékletek függvényében írta le (Geeraerts-Grondelaers 1995). Eszerint a négy fő vérmérséklet a szangvinikus, a kolerikus, a melankolikus és a flegmatikus, amelyek sorban a vér, a sárga epe, a fekete epe, valamint a nyák bőségének az eredménye. A négy vérmérséklet közül a szangvinikust tekintették a legelőnyösebb típusnak, mivel magába foglalta az életerős ember tulajdonságait, kapcsolatba hozták az életadó hővel és nedvességgel, a testnedvek közül a vér böségével jellemezték, valamint gyakran a fiatalságot és a tavaszt hozták összefüggésbe ezzel a természettel. Fizikai tulajdonságait tekintve a szangvinikus természet magas növésü, erőteljes, egészséges testalkattal rendelkezik, jó vérkeringéssel és emésztéssel, gyakran vörös hajjal és bőrrel. Személyisége szerint társaságkedvelö, jókedvű, kedves, szeret szórakozni, különösen a játékokat és a zenét kedveli. A magyar nyelvben a szangvinikus természetet olyan kifejezések jelzik, mint vérmes, bövérü, forróvérü, heves vérmérsékletü, tüzes vérü. 


\subsection{A VÉR mint ÉLETERő/TARTALOM}

Ahogyan a ROKONSÁG és az EMBERI TERMÉSZET kategóriájának határa esetenként homályos, ugyanez érvényes az ÉLETERŐ vs. EMBERI TERMÉSZET és az ÉLETERŐ vs. ROKONSÁG kategóriáira is. Az ÉLETERŐ és az EMBERI TERMÉSZET kategóriák esetében a szemantikai kapcsolat alapja az, hogy a szangvinikus személy bő vérellátással rendelkezik, így egészséges, életerős személyként konceptualizálódik.

(18) vértelen

(19) vérszegény

(20) elvérez

(21) kivéreztet

(22) vérbő

(23) vérmes

(24) van vér a pucájában (kellő bátorsággal rendelkezik valami megtételéhez)

(25) véresszájú (gyülölködő)

(26) vérpezsdítő

A vértelen vagy vérszegény olyan személyekre vonatkozik, akik nem elég energikusak, valamint olyan alkotásokat is jelölünk vele, amelyeknek a tartalma szegényes, például film, színdarab, könyv stb. A vérvesztés folyamatát mint tapasztalatot (nagyrészt az ÉRVELÉS HÁBORÚ metafora nyomán) nyerő-veszítő helyzetekre is kiterjesztjük, például versenyekre, sportversenyekre, vitákra vagy vizsgahelyzetekre. Ilyenkor valaki elvérez, vagy az ellenfelét kivérezteti. Vannak olyan kifejezések is, amelyek a vámpírhitre vezethetök vissza, amely szerint a vérszívók tulajdonképpen az életeröt szívják ki azáldozatukból a vérrel együtt (vérszivó, a vérét szivja). Amagyar néphagyományban a vámpírhit jóformán ismeretlen volt, bár a 18. században voltak olyan perek, amelyek vámpírjelenségekhez kötődtek (MNL. 5). A mai használatban metaforikusan vérszivónak nevezett személy „energiavámpír”, egy másik személy vérét szivja, azaz elveszi annak fizikai, érzelmi energiáját, idejét vagy pénzét. Másfelől, a vér bősége (vérbö, vérmes) energikus, aktív személyiséget jelez; ehhez kapcsolódik a van vér a pucájában kifejezés is, amely bátor, tettre kész személyiséget jelent. A puca szó eredetileg kislány, majd kisfiú nemi szervét jelentette (ÉrtSz.), majd férfi nemi szervet, ezért utalhat férfias jellegü tulajdonságra a kifejezés. A vérpezsditő melléknév többféle tevékenységet és jelenséget jellemez, például koncertet, táncot, ritmust. Mindezekben az esetekben a test vagy valamelyik testrész tartályként funkcionál, amely - Charteris-Black és Kövecses megállapításával egyetértve - a vérrel megtelik vagy kiürül belőle: mindez a FOLYADÉK A TARTÁLYBAN sémán alapul, ahol a vér bőségében lévő test életerőt, a vér hiánya pedig annak hiányát jelenti.

Az alábbi, (27)-es példában a ROKONSÁG és az ÉLETERŐ kategóriák határai elmosottak. A ROKONSÁG kiterjesztéséről a NEMZET fogalmára már volt a fentiekben szó (pl. Vérem!), szintúgy a vér közösséget összekötő szerepéről (pl. vérszerződés) és a vér életerőt és karakterjelleget hordozó funkciójáról. Alább a fáradt vér kifejezés- 
ben mindkét konceptualizáció jelen van: mind a közösséget összetartó anyag, mind pedig a vitalitást biztosító ,üzemanyag”.

(27) Ez a következő generáció már csak fáradt vér, meg sem közelíti az apákat. Sokkal mulyább és élhetetlenebb.

Az ÉLETERŐ konceptualizációja élettelen tárgyakra is használatos, itt inkább lényeget, tartalmat jelent, amely lehet gazdag vagy szegényes.

(28) A Jehova tanúi egy biblikus ámde azt kifacsaró, „vér nélküli” vallás.

A vér hiányának metaforikus jelentése a korpuszban több kontextusban elöfordul, akár popdallal, ízetlen étellel kapcsolatban, ahol a gyenge minőséget jelenti. A vér bősége itt is pozitív jelentéssel bír, míg a hiánya negatív jelentést hordoz, a vér túltengése pedig kontrollálatlan életeröt, meggondolatlanságot jelent.

\subsection{A VÉR mint ÉRZELEM}

Az érzelmek leírásában is rengeteg kifejezés tartalmazza a vér szót. A testnedv három alapvető profillal rendelkezik ezekben a kifejezésekben: a) olyan anyag, amely megtölti a testet vagy egy testrészt; b) hömérséklete van; c) dinamikus. Itt is sok nyelvi adatban felfedezhető a FOLYADÉK A TARTÁLYBAN séma (29-32).

(29) vérszemet kap (mohóvá, túlzottan bátorrá válik)

(30) arcába szökik a vér (haragot vagy szégyent is kifejezhet)

(31) fejébe tódul a vér (dühös lesz)

(32) elönti agyát a vér (dühös lesz)

Ezek a kifejezések metonimikus eredetüek, például a vérszemet kap arra a jelenségre utal, amikor felfokozott érzelmi állapotban valakinek a szemébe gyülik a vér. Érdekes kérdés az, hogy egy-egy érzelem esetében melyik testrész telik meg vérrel; a vérszemet kap példájában a SZEM konceptualizációjában megjelenő mohóságról lehet szó, például majd felfalta a szemével. Általánosságban a vér jelenléte izgalmi állapotot jelent, a konkrét érzelmet a szóban forgó testrész specifikálja. Így a fej és az agyat elöntő vér a magyarban dühöt jelent, a vérrel teli szem vakmerőséget és mohóságot, a vérrel megtelt arc pedig dühöt vagy szégyent.

Más kifejezésekben a vér hőmérséklete profilálódik: a forró vér dühöt, míg a hideg/fagyott vér félelmet jelent.

(33) megfagy az ereiben a vér

(34) vérlázító (itt a láz elsődlegesen forróságra utal, másodsorban dinamikus mozgásra, pl. lázasan keresgél)

(35) felforr a vére (dühös lesz)

(36) vérgőzös (fenyegetés) (indulatos) 
Végül néhány kifejezésben a vér dinamikus entitásként jelenik meg, bár ez is összefüggésbe hozható a hömérséklettel a hideg-dermedt és a forró-pezsgő kapcsolat révén.

(37) megdermed a vére (megijed, fél)

(38) pezseg a vére (izgatott)

Fontos kiemelni, hogy a legtöbb érzelem, amely a vér metaforikus kiterjesztésén alapul, negatív minősítésü, akár forró, akár pedig hideg hőmérsékletü: dühös, indulatos, mohó, rettegő vagy szégyenkező. Igaz, néhány kevés pozitív konnotációjú érzelem is található, mint például izgalom vagy bátorság. Ennek oka az a vélekedés lehet, hogy a testnedvnek kiegyensúlyozott mennyiségben kell jelen lennie a szervezetben.

\subsection{A VÉR mint INTENZITÁS}

Informális nyelvhasználatban a korpuszadatok szerint a vér olyan értelemben is használatos, mint „,nagyon” (39-42).

(39) vérprofi

(40) vérgazdag

(41) vérciki

(42) igazi, vérhü komcsi

Ez a jelentés hasonló az angol bloody szó jelentéséhez, míg azonban az angol fóként negatív értelemben használja, addig a magyar megfelelő pozitív és negatív értelmű szóhoz is kapcsolódhat. A vér ilyen jelentésének forrása több olyan használati esetben felfedezhető, ahol intenzitást fejez ki. Például a vérig sért esetében a következő szemantikai folyamat rekonstruálható: súlyos fizikai sérülés $\rightarrow$ súlyos mentális sértés (amely a MENTÁLIS SÉRTÉS FIZIKAI SÉRTÉS metaforán alapul). A vérig jelentése tehát a fizikailag súlyos $\rightarrow$ mentálisan erőteljes $\rightarrow$ intenzív jelentésváltozáson megy keresztül. Az MNSz-ben más olyan esetek is találhatók, amelyekben a vér absztrahált, intenzivitást jelölő értelmezése érvényesül (43-4).

(43) Tehát vér mindegy, hogy nem vagyunk egyformák...

(44) Fogadok, azt sem tudom, milyen a vércsoportom. Vér ciki!

Az első példában a 'teljesen', a másodikban pedig a 'nagyon' jelentést kapja a vér. A vér szemantikai kiterjesztése az intenzitás jelölésére kétféleképpen is magyarázható, illetve egyidejüleg két konceptualizációból ered. Az első a háború, halál kontextusa (45-9).

(45) vérre megy a játék

(46) vérig bosszant/ingerel 
(47) vérig gyaláz

(48) vérig gyötör

(49) vérig ütköző igazság

A fenti esetekben a vér kiserkenése (amelyet a vérig szó implikál) mint a fizikai inzultus eredménye metaforikusan a mentális inzultus súlyosságát jelzi. Az (50)-es és (51)-es példák párhuzamos létezése jól láthatóvá teszi a folyamatot:

(50) véresen komoly

(51) vérkomoly

A „nagyon” jelentés másik eredete az EMBERI TERMÉsZET konceptualizáció kontextusa. Olyan példák sorolhatók ide, mint vérprofi vagy vérhü, amelyekben az a konceptus jelenik meg, hogy a vér az emberi tulajdonságokat hordozó anyag. További példák:

(52) ízig-vérig nő (teljesen, egészen)

(53) vérig egyszerü nő

(54) Én valójában vérbeli hajléktalan vagyok, a hajléktalanok koronázatlan királya. (igazán, teljesen)

(55) igazi, vérhü komcsi

(56) A SW bizony vér sci-fi.

Az (52-6)-es példákban a vér szó helyettesíthető a vérbeli szóval, amely a vérben mint anyagban hordozott karakterjelleget, lényegi tulajdonságokat fejezi ki, és azt reprezentálja, hogy a szóban forgó entitás a karakterjegy tipikus egyede. Látható, hogy élettelen tárgyakat és fogalmakat is jellemzünk így, például vér sci-fi vagy vérbeli sci-fi, utalva a film prototipikus jellegére. Az EMBERI TERMÉSZET konceptualizációval összefüggésben az intenzivitás jelentése a vérnek az emberi életben és az emberi természet, személyiség kialakításában betöltött kulcsfontosságú szerepe nyomán alakulhatott ki.

\subsection{A VÉR mint VÉGZET (káromkodások)}

Az MNSz-ben a közösségi média oldalairól származó alkorpuszban a vér gyakran megjelenik egy tipikus szemantikai konstrukcióban, kifejezetten szlengben és káromkodásokban, például:

(57) Jó lenne, ha elhúznál a vérbe, a qtya sem kíváncsi a hülyeségeidre.

(58) Van aki az öntudatos rasszistákat küldi el a vérbe.

(59) A vevőt elhajtották a vérbe.

Valakinek az elküldése $a$ vérbe olyan értelmü, mint például elküldeni a pokolba. A kérdés az, hogy miért a vér szerepel ezekben a példákban. Mivel a kifejezés ere- 
dete nem ismert, két lehetséges magyarázat következik, amelyek mindketten a szitok eredeti funkciójával hozhatók összefüggésbe. A szitokszavak nagy része társadalmi tabukból ered, amelyek három fő témát érintenek: a szexualitást, a testi kiválasztást és a természetfelettit. Az első két csoporton belül helyezkednek el bizonyos tabunak minősülö testrészek és azokhoz tartozó funkciók (Galgóczi 2008: 6). A káromkodás, szitkozódás olyan verbális agresszióként fogható fel, amelyben a beszélő célja megalázni és elpusztítani a másik személyt.

Az első lehetséges magyarázat abból indul ki, hogy a magyar káromkodások jó része betegségekre utal, mivel a népi kultúrában ezek eredetileg átkok voltak (Galgóczi 2008: 7). Az átkok célja az volt, hogy a másik személyt valamely betegség megtámadja és elpusztítsa, erre példák az alábbiak (60-5):

(60) A fene vigye el!

(61) A nyavalya essen bele!

(62) A guta vigye el!

(63) Vigye el a frász!

(64) A rossebbe!

(65) Menjen a francba!

Figyelemre méltó, hogy az ,elküldés” fogalma mindegyik átokban megtalálható: vagy a betegség vigye el a megátkozott illetőt, vagy pedig öt kívánja a betegségbe juttatni a rosszakaró. A mai köznyelvben már nem ismert betegségnevek különbözö, gyakran pontosan nem meghatározott, azonos tüneteket mutató betegségre utaltak. A fene fekélyt, gennyes sebet, a nyavalya belső kórt, betegséget, a guta szélütést, a frász görcsös rohamokat, a rosseb (rossz seb) és a franc pedig vérbajt, szifiliszt jelent (ÉrtSz.). Az esetünkben fontos franc metonimikusan utal a francia bajra, mert úgy tartották, hogy a szifiliszt a buja hírü francia katonák hozták be Európába a 15. században. Mivel a szifilisz magyar neve vérbaj, a vérbe küldés aktusa származhat a vérbajba küldés átkából, ahol a vér metonimikusan utal a vérbajra.

A második feltételes magyarázat szintén a magyar szleng és a szitokszók társadalmi funkciójából indul ki. Kis Tamás hangsúlyozza, hogy a szlengnek fontos szerepe van a csoportszintü nyelvhasználatban, méghozzá jellemzően egy nagyobb csoporton belüli kisebb csoport fejleszti ki, amely érzelmileg szorosan összetartozik (Kis 2007). A szleng valójában egy kisebb csoport verbális lázadása a hierarchia ellen, amely igazságtétellel is jár, ahol a feszültséget humorral oldják fel (Kis 2007: 459-60). A szleng funkciója hasonló a középkori karneválokon megjelenő groteszk realizmus ábrázolásmódjával (karneváli groteszk), ahol a szereplők célja az egyenlőtlenség lerombolása volt a degradálás, parodizálás eszközével. Ez az elmélet Bahtyintól származik, aki Rabelais múvészetét elemezte a karneváli groteszk realizmussal összefüggésben (Bahtyin 1982/2002). Bahtyin fogalma szerint a groteszk test a degradálás különböző módjainak, a bántásnak és az átkozásnak a célpontja, amely a reneszánsz irodalom groteszk, gyakorlatias ábrázolásának fontos része. „A „kacskaringós” káromkodások számtalan változata vagy a „menj a ...-ba” típusú kifejezések teljesen a groteszk ábrázolás módszere szerint fokoznák le azt, akit szidalmaznak, vagyis 
abszolút topográfiai értelemben a testi „lent”-be; a szülés, a nemi szervek zónájába, a testi sírba (vagy a testi pokolba) küldik a címzettet megsemmisülni - és újjászületni” (Bahtyin 1982/2002: 37-8). Valóban, a magyar szlengben több kifejezés szól arról, hogy valaki elküldi a másikat a szülei nemi szervébe vagy azokra jellemző váladékba (pl. gecibe, amely ondót jelent), amelyek mindegyike a személy születésénél fontos szerepet játszottak. Például, amikor valakit elküldenek a véres gecibe, akkor - az elmélet szerint - visszaküldik a születés előtti állapotba, amelyet az apához és az anyához tartozó testnedvek idéznek fel metonimikusan. A vérbe küldés aktusa tehát ilyen kontextusban is értelmezhető: a vér a születés körülményeire utal metonimikusan, ilyen módon semmisítve meg a célzott személyt.

\section{A vér profiljai az egyes konceptualizációkban}

Az itt bemutatott konceptualizációkban a vér a következő profilokkal rendelkezik: szín, anyag, hőmérséklet, minőség, mennyiség, (betegség/születés) tünet(e), mozgás, ital. A profilok és a konceptualizációk összetett hálózatot alkotnak, bár ennek bemutatása kétdimenziós ábrán nehézkes (1. ábra, vö. Baranyiné Kóczy [bírálat alatt]).

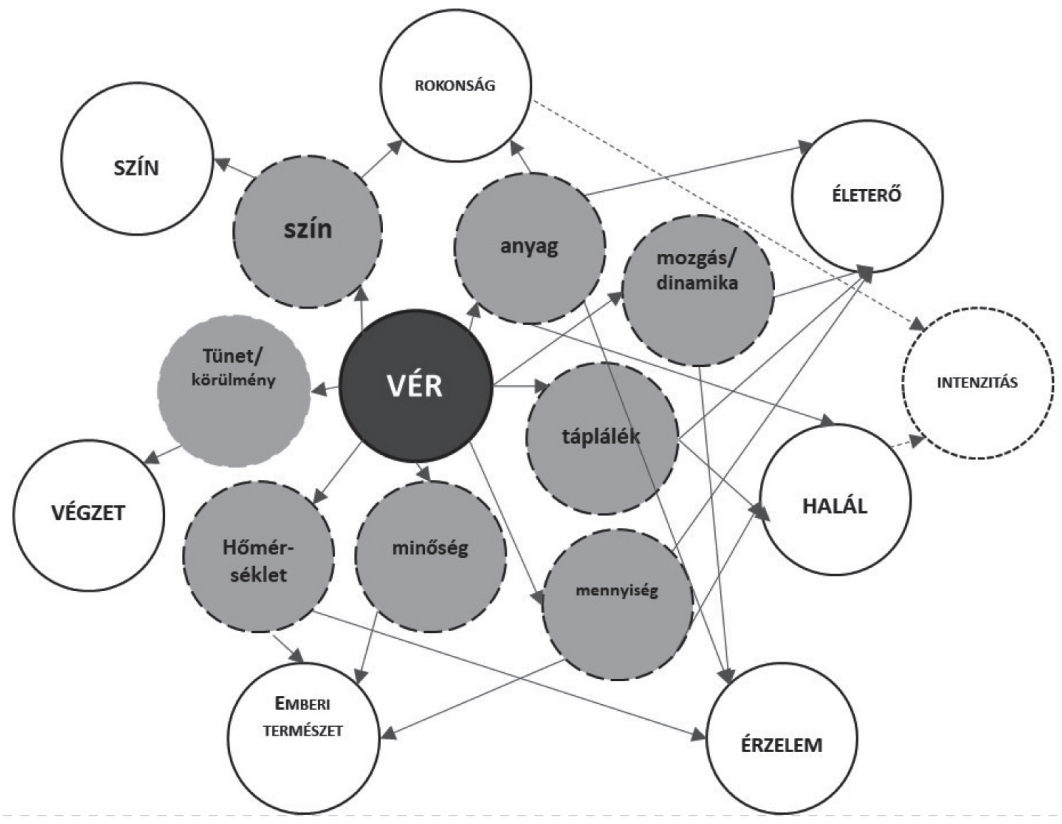

1. ábra. A vÉR kulturális konceptualizációinak és profiljainak hálózata

A metonimikus alapú szín konceptualizációban természetesen a vér színe kap profilt. A számos nyelvben jelen lévő ROKONSÁG konceptualizáció esetében (vö. pl. Charteris-Black 2001) a vér elsősorban anyagként (vérrokon), másodsorban színként 
(kékvér) profilálódik. Az ÉLETERö konceptualizációjában a vér anyag, szubsztancia (vérbö), mozgó/dinamikus folyadék (vérpezsditö) vagy táplálék (a vérét szívja). A HALÁL konceptualizációjában szintén elsősorban az anyag (vér tapad a kezéhez), a mozgó/dinamikus folyadék (ott vér folyik), a táplálék (vérszomjas) és a mennyiség (vérzivatar) profilok jelennek meg. Az ÉRZELMEK esetében a tartályban lévő anyag (fejébe tódul a vér), a hőmérséklet (felforr a vére) és a mozgás/dinamika (pezseg/ megdermed a vére) profilálódik. A EMBERI TERMÉSZETtel kapcsolatban jellemzően a vér minősége profilálódik: minősége (sürü vérü), mennyisége (vérmes, amelynek jelentése: „Nagyon bővérü, ill. sürü vérü < személy>”, ÉrtSz.) és hőmérséklete (heves vérmérsékletü). A vÉGZET esetében két értelmezési lehetőséget vázoltam, amelyekben a vér vagy egy betegség tünetének vagy pedig a születés körülményeinek metonimikus jelölöje.

Az INTENZITÁs konceptualizációja két másik konceptualizációból eredeztethetö, így a HALÁL (véresen komoly, vérkomoly) és a ROKONSÁG (vérgazdag, vérig hü, vérhü) tartományából. A vérnek ilyen, az informális nyelvhasználatban mára elterjedt jelentése (mint 'nagyon') még az EMBERI TERMÉSzET konceptussal is összefüggésbe hozható, például: Ne táplálj vérmes reményeket! (Jelentése itt: túlzó.)

Összeségében elmondható, hogy a véR leggyakrabban anyagként, azaz szubsztanciaként profilálódik, ez a profil dominál a ROKONSÁG, a HALÁL és az ÉLETERÖ konceptualizációban. Ennek magyarázata az, hogy mind a három konceptualizációban a metafora alapja a vér mint ÉLETET ADÓ ANYAG. A vér mennyisége azért meghatározó az ÉLETERŐ és az EMBERI TERMÉSZET kategóriában, mert a két konceptualizáció összefügg: az emberi természet meghatározásának alapja az, hogy az embert mint tartályt milyen mértékben tölt meg a vér, így az életerő mértéke a temperamentum körvonalazásában is fontos szerepet kap. Ez az egyik alapvetése a négy testnedv elméletében a szangvinikus temperamentumnak, amely Lakoff és Kövecses érvelése szerint az érzelmek metaforikus megjelenítésének egyik fö kulturális modellje is (Lakoff-Kövecses 1987; Geeraerts-Grondelaers 1995). A vér mennyisége a HALÁL konceptualizációban egészen másképp jelenik meg, nem a testtartályon belül, hanem azon kívül. Az ÉRZELMEK kifejezésében a vér mozgó/dinamikus jellege és a hőmérséklete profilálódik. A vér mozgása, dinamikája tehát az ÉLETERŐ és az ÉRZELMEK konceptualizációjában érvényesül. Ennek oka az, hogy mindkét tartományban erődinamikai séma érvényesül, amelyben az erőhatás eredménye az anyag mozgása (Talmy 1988). Ez a séma, mint ahogy Kövecses is rámutat, az érzelmek konceptualizációjában is gyakran tetten érhető (Kövecses 2000).

\section{5. Összegzés}

A hétköznapi emberi tapasztalat szerint a vér az élethez szükséges legfontosabb testnedv, amely az egyes kultúrákban különböző konceptualizációk forrása kulturális metaforák, metonímiák és sémák formájában. A tanulmány azt a nézetet támasztja alá, hogy egy olyan szimbolikus anyag, mint a vér, amelynek története az emberi kognícióban a legrégebbi idökig nyúlik vissza, összetett szempontrendszerrel, azaz 
a társadalmi, történelmi, vallási, egyszóval világnézeti kontextusok vizsgálatával elemezhető (Sharifian et al. 2008; Maalej-Yu 2011). A kulturális antropológiában feltárt eredményeket a nyelvtudomány eddig kevéssé, legalábbis nem kellő mértékben vonta be a kutatásaiba.

A tanulmány a bevezetőben említett vizsgálati korlátok (az értelmezés nehézségei, a kategóriahatárok elmosódottsága) mellett a nyelv, a kultúra és a kogníció együttes elemzésével rekonstruálja a magyar véR fogalom konceptuális hálózatát, amelynek fö kategóriái a következők:

A vér mint szín (pl. vércse, vörheny)

A vér mint HALÁL (pl. vérontás, vérdíj)

A VÉR mint ROKONSÁG (pl. testvér, vérbeli fönemes)

A VÉR mint EMBERI TERMÉSZET (pl. vérmes, halvérü, könnyüvérü)

A vÉR mint ÉLETERÖ/TARTALOM (pl. vérbö, vérszegény)

A vÉR mint ÉRZELEM (pl. vérgözös, vérszemet kap)

A vÉR mint INTENZITÁs (pl. vérgazdag, vérig egyszerü)

A VÉR mint VÉGZET (pl. elküldi a vérbe)

A kutatás során kiemeltem, hogy a vér figuratív használata gyakran kulturális modellekben gyökerezik, amelyek a magyar hagyományokon és hiedelmeken alapulnak (1. táblázat):

1. táblázat. A vér kulturális konceptualizációi és releváns kulturális modelljei

\begin{tabular}{|c|c|}
\hline Kulturális konceptualizációk & Kapcsolódó kulturális modellek \\
\hline A VÉR mint SZÍN & A VÉR A PIROS SZÍN PROTOTIPIKUS ANYAGA \\
\hline A VÉR mint HALÁL & $\begin{array}{l}\text { MÁRTÍRSÁG } \\
\text { ELSŐ VÉRIG TARTÓ PÁRBAJOZÁSI TRADÍCIÓ }\end{array}$ \\
\hline A VÉR mint ROKONSÁG & $\begin{array}{l}\text { A VÉR A GENETIKAI ÁLLOMÁNYT ÉS KARAKTERT } \\
\text { HORDOZÓ ANYAG } \\
\text { A VÉRSZERZŐDÉS ÉS A VÉRTESTVÉRSÉG RÍTUSA } \\
\text { A VÉRBOSSZÚ HAGYOMÁNYA }\end{array}$ \\
\hline A VÉR mint EMBERI TERMÉSZET & A NÉGY TESTNEDV ELMÉLETE \\
\hline A VÉR mint ÉLETERŐ/TARTALOM & $\begin{array}{l}\text { VÁMPÍROK A NÉPHITBEN } \\
\text { A NÉGY TESTNEDV ELMÉLETE }\end{array}$ \\
\hline A VÉR mint ÉRZELEM & $\begin{array}{l}\text { A NÉGY TESTNEDV ELMÉLETE: } \\
\text { A VÉR MENNYISÉGÉNEK ÉS HŐMÉRSÉKLETÉNEK } \\
\text { KIEGYENSÚLYOZATLANSÁGA NEGATÍV ÉRZELMEKET } \\
\text { EREDMÉNYEZ }\end{array}$ \\
\hline A VÉR mint INTENZITÁS & $\begin{array}{l}\text { A vér látványa extrém helyzetben kerül elö, intenzív } \\
\text { mentális állapotot idéz elö. } \\
\text { A vÉR MINT HALÁL és a VÉR MINT ROKONSÁG } \\
\text { konceptualizációból ered. }\end{array}$ \\
\hline A VÉR mint VÉGZET & 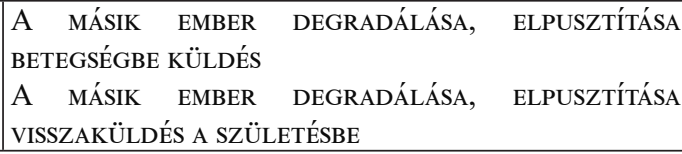 \\
\hline
\end{tabular}


A magyar nyelvben a vÉR kulturális konceptualizációi sokféle, igen eltérő tapasztalatokban gyökereznek. A vérhez kapcsolódó egyik alapvető asszociáció a magyar történelmi mérföldkő, a hét vezér megállapodását kísérő vérszerződés. Ez a szertartás a vértestvérség létrejöttét eredményezte közöttük, amely a ROKONSÁG MINT VÉR metaforán alapult, és esetenként még ma is tartják esküvőkön ezt a szokást. ${ }^{1}$ Másfelől, a vÉR figuratív használatában ma is találhatunk újszerű fejleményeket: ilyen az INTENZITÁs konceptualizációja, amely az informális nyelvben vált újabban elterjedtté. A testrészek és testnedvek figuratív alkalmazásának megértéséhez szükséges tehát az univerzális tapasztalatok mellett a kulturális kontextus számbavétele is, akár évezredes, akár új nyelvi fejleményről van szó.

\section{SZAKIRODALOM}

Bahtyin, Mihail 1982/2002. François Rabelais müvészete, a középkor és a reneszánsz népi kultúrája. Ford. Könczöl Csaba. Európa Könyvkiadó, Budapest.

Bańczerowski, Janusz 2003. A kéz nyelvi képe a magyar nyelvben. Magyar Nyelv 99: 427-34.

Bańczerowski Janusz 2007. A fej nyelvi képe a magyar nyelvben. Magyar Nyelvör 131: 385402.

Bańczerowski Janusz - Dziewonska-Kiss Dorota 2013. A szív képe a magyar és a lengyel frazeológiában. Magyar Nyelvőr 137: 336-42.

Baranyiné Kóczy Judit 2017. Mi a kulturális metafora? Magyar Nyelvőr 141: 404-25.

Baranyiné Kóczy Judit 2018. A SZEM konceptualizációjáról. Nyelvtudományi Közlemények 114: 7-28. https://doi.org/10.18349/MagyarNyelv.2018.2.156

Baranyiné Kóczy, Judit 2019. 'He cracked his head feverishly': Conceptualizations of HEAD and THINKING in Hungarian. In: Iwona Kraska-Szlenk (ed.): Embodiment in Cross-Linguistic Studies: The 'Head'. Brill, Leiden, 219-44. https://doi.org/10.1163/9789004392410_013

Baranyiné Kóczy, Judit 2020. Keeping an eye on body parts: Cultural conceptualizations of the 'eye' in Hungarian. In: Iwona Kraska-Szlenk (ed.): Body Part Terms in Conceptualization and Language Usage. John Benjamins Publishing, Amsterdam, Philadelphia, 216-245. https://doi.org/10.1075/clscc.12.c10koc

Baranyiné Kóczy Judit (bírálat alatt). A testrészek konceptualizációja mint hálózat.

Brenzinger, Matthias - Kraska-Szlenk, Iwona (eds.) 2014. The Body in Language: Comparative Studies of Linguistic Embodiment. Brill, Leiden. https://doi.org/10.1163/9789004274297

Büky László 2012. „....testben, lélekben tisztán...” - A test(részek) kontingenciái és értékállapotaik Füst Milán költői nyelvében. Magyar Nyelvör 136: 420-39.

Charteris-Black, Jonathan 2000. Figuration, lexis and cultural resonance: A corpus based study of Malay. Pragmatics 10: 281-300. https://doi.org/10.1075/prag.10.3.02cha

Charteris-Black, Jonathan 2001. Blood sweat and tears: A corpus based cognitive analysis of 'blood' in English phraseology. Studi Italiani di Linguistica Teorica e Applicata 30: $273-87$.

Csábi, Szilvia 2005. Alternative Conceptualization in English and Hungarian Idioms. PhDdolgozat. Eötvös Loránd Tudományegyetem, Budapest.

ÉrtSz.= Bárczi Géza - Országh László (főszerk.) 1959-1962. A magyar nyelv értelmező szótára I-VII. Akadémiai Kiadó, Budapest.

1 https://www.szeretlekmagyarorszag.hu/nem-volt-hagyomanyos-eskuvoje-verszerzodestkotott-parjaval-a-viszkis/. 
Evans-Pritchard, Edward Evan 1933. Zande Blood-Brotherhood. Africa 6: 369-401. https:// doi.org/10.2307/1155555

Galgóczi László 2008. A nyelvi agresszió és diakrón formái a magyarban. Acta Academiae Paedagogicae Agriensis XXXV: 5-28.

Geeraerts, Dirk - Grondelaers, Stefan 1995. Cultural traditions and metaphorical patterns. In: J. R. Taylor - R. E. MacLaury (eds.): Language and the Construal of the World. Mouton de Gruyter, Berlin, New York, 153-79.

Gibbs, Ray W. Jr. 2006. Embodiment and Cognitive Science. Cambridge University Press, Cambridge. https://doi.org/10.1017/CBO9780511805844

Hauser-Schäublin, Brigitta 1993. Blood: Cultural effectiveness of biological conditions. In: Barbara D Miller (ed.): Sex and gender hierarchies. Cambridge University Press, Cambridge, New York, 83-106.

Johnson, Mark 1987. The Body in the Mind. The Bodily Basis of Meaning, Imagination and Reason. The University of Chicago Press, Chicago. https://doi.org/10.7208/ chicago/9780226177847.001.0001

Kirkpatrick, Betty (ed.) 1992. Brewer's Concise Dictionary of Phrase and Fable. Cassells, London.

Kis Tamás 2007. Szleng és karnevál. In: Benő Attila - Fazakas Emese - Szilágyi N. Sándor (szerk.): Nyelvek és nyelvváltozatok. Köszöntö kötet Péntek János tiszteletére. Anyanyelvápolók Erdélyi Szövetsége Kiadó, Kolosvár, 455-64.

Kövecses, Zoltán 1990. Emotion Concepts. Springer, New York. https://doi.org/10.1007/978$1-4612-3312-1$

Kövecses, Zoltán 2002. Metaphor: A Practical Introduction. Oxford University Press, Oxford.

Kövecses, Zoltán 2005. Metaphor in Culture: Universality and Variation. Cambridge University Press, Cambridge. https://doi.org/10.1017/CBO9780511614408

Kraska-Szlenk, Iwona 2014. Semantics of Body Part Terms: General Trends and a Case Study of Swahili. Lincom, München.

Kraska-Szlenk, Iwona (ed.) 2019. Embodiment in Cross-Linguistic Studies: The 'Head'. Brill, Leiden. https://doi.org/10.1163/9789004392410

Kraska-Szlenk, Iwona (ed.) 2020. Body Part Terms in Conceptualization and Language Usage. John Benjamins Publishing, Amsterdam, Philadelphia.

Lakoff, George - Johnson, Mark 1980. Metaphors We Live By. University of Chicago Press, Chicago.

Lakoff, George - Kövecses, Zoltán 1987. The cognitive model of anger inherent in American English. In: Holland, Dorothy - Quinn, Naomi (eds.): Cultural Models in Language and Thought. Cambridge University Press, Cambridge, 195-221. https://doi.org/10.1017/ CBO9780511607660.009

Maalej, Zouheir 2004. Figurative language in anger expressions in Tunisian Arabic: An extended view of embodiment. Metaphor and Symbol 19(1): 51-75. https://doi. org/10.1207/S15327868MS1901_3

Maalej, Zouheir 2008. The heart and cultural embodiment in Tunisian Arabic. In: Farzad Sharifian - René Dirven - Ning Yu - Susanne Niemeier (eds.): Culture, Body, and Language: Conceptualizations of Internal Body Organs across Cultures and Languages. Mouton de Gruyter, Berlin, New York, 395-428.

Maalej, Zouheir - Ning Yu 2011. Introduction: Embodiment via Body Parts. In: Zouheir Maalej-Ning Yu (eds.): Embodiment via Body Parts. Studies from various languages and cultures. John Benjamins Publishing, Amsterdam, Philadelphia, 1-20. https://doi. org/10.1075/hcp.31.03maa

MNL. 5. = Ortutay Gyula 1982. Magyar néprajzi lexikon V. Akadémiai Kiadó, Budapest.

MNSz. = Magyar Nemzeti Szövegtár. http://corpus.nytud.hu/mnsz/. 
Mulsoff, Andreas 2007. What role do metaphors play in racial prejudice? The function of antisemitic imagery in Hitler's Mein Kamp. Patterns of Prejudice 41/1: 21-43. https://doi. org/10.1080/00313220601118744

Oravecz Csaba - Váradi Tamás - Sass Bálint 2014. The Hungarian Gigaword Corpus. In: Proceedings of LREC 2014. http://mnsz.nytud.hu.

Sharifian, Farzad 2003. On cultural conceptualisations. Journal of Cognition and Culture 3(3): 187-207. https://doi.org/10.1163/156853703322336625

Sharifian, Farzad 2011. Cultural Conceptualisations and Language: Theoretical Framework and Applications. John Benjamins Publishing, Amsterdam, Philadelphia.

Sharifian, Farzad 2017. Cultural Linguistics. John Benjamins Publishing, Amsterdam, Philadelphia. https://doi.org/10.1007/978-981-10-4056-6

Sharifian, Farzad - René Dirven - Ning Yu - Susanne Niemeier (eds.) 2008. Culture, Body, and Language: Conceptualizations of Internal Body Organs across Cultures and Languages. Mouton de Gruyter, Berlin, New York. https://doi.org/10.1515/9783110199109

Simó, Judit 2008. It's not all about the brain: A cross-linguistic exploration of body part metaphors in chess. The Ninth Conference on Conceptual Structure, Discourse, and Language (CSDL 9), October 2008, Cleveland, Ohio.

Simó, Judit 2011. Metaphors of blood in American English and Hungarian: A cross-linguistic corpus investigation. Journal of Pragmatics 43: 2897-910. https://doi.org/10.1016/j. pragma.2011.05.004

Szemerkényi Ágnes 2009. Szólások és közmondások. Osiris Kiadó, Budapest.

Talmy, Leonard 1988. Force dynamics in language and cognition. Cognitive Science 12: 49100. https://doi.org/10.1207/s15516709 $\operatorname{cog} 1201 \_2$

Turner, Victor 1977. The ritual process: Structure and antistructure. Cornell University Press, Ithaca, New York.

\author{
Baranyiné Kóczy Judit \\ egyetemi adjunktus \\ Széchenyi István Egyetem \\ https://orcid.org/0000-0002-6685-7133
}

\author{
SUMMARY \\ Baranyiné Kóczy, Judit

\section{From vérszerzödés 'blood oath' to vérciki 'bloody awkward': Cultural conceptualization of VÉR 'blood' in Hungarian}

Historical, ethnographic, and theological studies witness the diversified symbolism and decisive cultural role of 'blood'. The paper explores the role of the body fluid concerned in conceptualization, from the point of view of cognitive-cultural linguistics. The aim is to unfold the metaphorical and metonymic domains of Hungarian vér 'blood' and the culturespecific factors of world view (beliefs and events) that determine the role of that body fluid in the cultural cognition of the Hungarian community, on the basis of relevant expressions found in standard handbooks and data of the Hungarian National Corpus. Such factors include DEATH, KINSHIP, HUMAN NATURE, VITALITY, EMOTION, INTENSITY, and MALEDICTION. The paper depicts conceptualizations of 'blood' and its profiled features in the individual domains in a network.

Keywords: cultural conceptualization, metaphor, embodiment, blood. 